\title{
2. Danish Drug Policy: Between Repression and Harm Reduction
}

Esben Houborg \& Kim Møller

In a Nordic perspective, Danish drug policy has traditionally been considered to be fairly liberal (Bruun \& Rosenqvist I980; Moeller 20I9). This has been due, among other things, to a depenalization of the possession of drugs for personal use between I969 and 2004, and early and extensive use of opioid substitution treatment (OST). However, in recent years this picture has become more complicated. On the one hand Danish drug policy has moved in a more repressive direction, but on the other hand, Denmark has also introduced two of the most controversial harm reduction measures: OST with heroin and drug consumption rooms. It appears that priorities in Danish drug policy have become rather contradictory. In this chapter, we will discuss the recent developments in Danish drug policy with a perspective on the background of the history of modern Danish drug policy.

In this chapter we analyse Danish drug policy from the point of view of how it defines the drug user as a social citizen and, in close relation to this, how it affects the distribution of drug-related harms and risks, and the responsibility for handling them.

Different drug policies and policy instruments affect drug-related risks and how these risks are distributed in society (Mugford I99I; Benoit 2003). Some risks are intrinsic to specific drugs. Cannabis, heroin, and cocaine have different risk profiles. A drug policy that reduces the number of people who use these drugs will therefore minimize the number of people who are exposed to these risks. However, risks are not just intrinsic. There

How to cite this book chapter:

Houborg, Esben and Møller, Kim. Danish Drug Policy: Between Repression and Harm Reduction. In: Retreat or Entrenchment? Drug Policies in the Nordic Countries at a Crossroads, edited by Henrik Tham, I3-36. Stockholm: Stockholm University Press, 202I. DOI: https:/doi.org/Io.I6993/bbo.b. License: CC BY 4.०. 
are also extrinsic risks, which are caused not by the drugs but by the circumstances under which the drugs are used. How drug policy affects the conditions under which drugs are used will therefore either increase or decrease such extrinsic risks. Rigorously enforced drug prohibition will increase this type of risk, while harm reduction measures will reduce them. The risks and harms mentioned here are the ones that affect the drug user, but there are also risks and harms that affect those other than the drug users. Families, local communities, and societal institutions can also be harmed by the presence of illicit drugs and an illicit drug market. Drug policy can also reduce the risks of such indirect harms in different ways. Making controlled substances legally available can, for example, reduce certain types of organized crime, depending on the specific way this is done. It should therefore be apparent that drug policy involves a number of not just technical decisions, but also political priorities about which harms to reduce and which trade-offs to accept in terms of increasing the potential for other harms and exposing parts of the population to such risks.

\section{Drug Policy and Social Citizenship}

Benoit (2003) argues that the way a state's drug policy addresses drug-related risks may be influenced by the way it addresses other socio-economic risks such as illness and unemployment. With reference to welfare-regime theory (Esping-Andersen I990), she argues that some states make it an individual responsibility to manage and bear the costs of socio-economic risks, while others, to different extents, make it a collective responsibility. A residual welfare state like the one in the USA, where the responsibility for managing socio-economic risks is, to a large degree, delegated to individuals and families, will, according to Benoit, also tend to individualize drug-related risks. On the other hand, welfare states like the Nordic welfare states, where the responsibility for managing socio-economic risks is, to a large extent, collective, will also tend to collectivize drug-related risks.

The way that drug policy distributes drug-related risks, and the costs of reducing such risks, can be seen to be part of the practices that define and give form and content to social citizenship. According to Turner (I993), citizenship can be defined as 'the set 
of practices (juridical, political, economic, and cultural) which define a person as a competent member of society, and which as a consequence shape the flow of resources to persons and social group' (op.cit. p. 2). Citizenship involves two dimensions: the constitution of social membership and the allocation of resources within a population. These two dimensions are affected by the drug control policy (drug legislation and its enforcement) and the prevention, treatment, and harm reduction policies of a country. Does drug policy criminalize the drug user and constitute him or her as a deviant? Does it recognize risks related to drug use and, if so, to which extent does it do so? Does it, for example, recognize risks associated with being an active drug user by providing different kinds of harm reduction measures? The association between drug policy and citizenship is not unfamiliar in drug policy analysis. Some analyses, for example, associate harm reduction with new public health as a way to promote a neo-liberal, health conscious, and self-responsible citizen (Fomiatti, Moore, \& Fraser 20I9; Tammi and Hurme 2007), while others have seen drug policies as both promoting and restricting social citizenship (Benoit 2003; Houborg \& Bjerge 20 I I; Houborg, Søgaard, \& Mogensen, 2020). Therefore, when we analyse Danish drug policy we will study how different drug policy initiatives have affected the rights and obligations of drug users; the extent to which such initiatives have served as mechanisms of inclusion and exclusion of drug users; and how they have influenced drug users' access to resources.

\section{0s: The Birth of Modern Danish Drug Policy and Criminalisation of Drug Users}

In the following sections we will present a history of Danish drug policy based on previous research and historical sources. In the appendix we provide a table of the sources.

Modern Danish drug policy can be said to have been born in I955 when the Danish parliament passed the law on euphoriant substances (lov om euforiserende stoffer). This legislation made possession of illicit drugs for personal use a criminal offence in Denmark. Previously, criminal and administrative sanctions were only aimed at regulating the supply of drugs, mainly through the regulation of doctors and chemists. During the Second World 
War and its immediate aftermath, the first drug scene developed in Denmark when groups of mainly marginalized people in Copenhagen started to buy, sell, and use drugs that were procured from criminal activities like prescription fraud and burglaries. The white paper that was the basis for the new legislation distinguished the members of this drug scene from people who got addicted to drugs, mainly morphine, after receiving medical treatment. This old group of drug-dependent people were called 'morphinists', while the new group of drug users were called 'euphomaniacs' because they were seen to have developed a taste for the intoxicating effects of drugs rather than self-medicating. Another difference was that drug users were no longer isolated individuals who mainly used drugs as self-medication because of what was seen to be physical dependence or mental defects, but a social phenomenon that grew out of the seediest parts of the city's vice and bar districts (Indenrigsministeriet I953). Furthermore, the new phenomenon was seen to be contagious because experienced drug users would introduce novices to drugs, in part to create new avenues to get access to drugs (Indenrigsministeriet I953; Jepsen I966). This was part of the reason why drug users for the first time came to the attention of the criminal justice system, in the form of the vice police. Another reason was that drugs were mainly procured through criminal activities. The new phenomenon was considered to be a problem, to the extent that in I949 a drug unit was established under the health (and vice) police in Copenhagen. This unit started a register for these 'euphomaniacs', with around 300 persons included on the register in 1950.

Drug use was, therefore, associated with crime for the first time and became an issue for the criminal justice system in Denmark. However, because the drug legislation did not criminalize possession of drugs for personal use, the police lacked the tools to control the new drug scene, particularly because they found it difficult to make cases against distributors. The fear was that the lack of proper tools would lead to more organized drug trafficking. For this reason, the police wanted to be able to raise drug cases against drug users, not to criminalize drug users but to make cases against distributors (Indenrigsministeriet I953: I 24f). This may also be the reason why drug use was not criminalized, 
only possession for personal use was. The intention of the legislators to use criminalization of drug users mainly to criminalize distributers was stated in the preliminary legislative work, which came to have important consequences for later developments of Danish drug policy. The drug legislation from I955 made it possible to sentence offenders to up to two years imprisonment, but in law enforcement practice imprisonment would not be used in cases that only concerned possession for personal use (Jepsen I966). But the new legislation did provide police in Copenhagen with legal instruments that made it possible to control the new drug scene (Jepsen 2008). However, in practice, the drug policy was more nuanced, because while the 'euphomaniancs' were criminalized and registered by the police, 'morphinists' were registered by the health authorities and this group was mainly controlled by the medical system. In other words, underclass drug users were constituted as 'criminals' while middle- and upper-class drug users were constituted as patients (Jepsen 2008: I 56). The policy constituted and handled the drug problem as two limited problems. First, the development of 'euphomania' in a particular anomic social environment in Copenhagen that could be controlled by the police. Second, the development of 'morphinism' among people who were mentally and/or emotionally disposed to becoming dependent on drugs, which could be reduced by controlling the medical system. In both cases drug users were constituted as deviant. The drug policy was mainly designed to control and contain these rather marginal forms of deviancy in Danish society.

\section{0s and 1970s: A Dual Track Drug Policy - Decriminalization of Drug Users}

From the early I960s a new drug phenomenon started to emerge in Denmark that differed from the known 'morphinists' and 'euphomaniacs'. This involved young people who used cannabis. It was at first mainly associated with the 'youth rebellion', but later also as a more mainstream phenomenon. The new phenomenon was called 'youth-euphomania' or 'youth-narcomania', and in I968 an advisory board of experts was established called the 'Committee on youth-narcomania' to advice the government on 
the issue. This committee initiated the production of knowledge about the new phenomenon, mainly through surveys of drug use among young people in different parts of the country, often populations of young people attending school or other kinds of education. Outside the committee the new drug phenomenon also became the topic for more theoretically based sociological and criminological research (Manniche, Holstein, \& Boolsen I972a; I972b; Ulff-Møller I97 I; Ulff-Møller \& Jørgensen I972; Voss \& Ziirsen I97I; Winsløw \& Holstein I972). The studies showed an increase in young peoples' exposure to drugs, experimentation with drugs, and use of drugs. From I968 to I970 the proportion of young people who participated in school surveys that had tried cannabis increased from little over I0\% to around one fourth, regular use of drugs had risen from I $\%$ to $4 \%$, and while less than one in four had been in favour of cannabis legalisation in I968, it was a little under half in I970 (Jepsen 2008; Storgaard 2000).

'The young drug user' also started to appear in the different institutions that dealt with young people and drug users: the child and youth care services, the psychiatric system, and the prison system. Within these institutions, the young drug users constituted a type of client, patient, or prisoner that they had never seen before, and for which they were neither epistemologically nor methodologically, and particularly not culturally, prepared to deal with. As a consequence, both public and private drug treatment institutions for young people started to develop, which soon became a new and specialized drug treatment system in Denmark (Houborg 2008). This system, sanctioned by the majority of the parties in the Danish parliament, was based on an understanding of drug use as a symptom of other social problems and of maladaptation to society. Drug treatment would involve resocialization and social rehabilitation, but the main instrument to reduce drug demand would be a social welfare policy that would, more broadly, prevent drug experimentation and the development from drug experimentation to problematic drug use (Houborg 2006, 2008; Kontaktudvalget I969, I970).

The surveys and the ideas governing the treatment system constituted young people as being exposed to drugs through their social networks, and drug experimentation as being determined by micro and macro social processes. Drug use was not as much a 
consumption choice as it was a product of being a young person in contemporary Danish society. Drug use was no longer something that developed in a particular anomic social environment or something that mainly involved mentally and emotionally afflicted individuals. Rather, it was a practice that developed in the normal social environments and through the normal social relations among young people in Denmark.

In 1968, the government proposed new drug legislation to prevent organized crime developing on the market for illicit drugs. This was partly due to pressure from Norway and Sweden that Denmark needed to introduce a stricter drug policy to match the development in these countries (Jepsen 2008; Storgaard 2000). With this background, a new section was added to the penal code (\$I9I) that would mean imprisonment for up to six years for violations of the drug legislation involving professional distribution and trafficking of drugs. However, during the political process in the parliament, a policy of depenalization of drug users and a differentiation between cannabis and 'hard' drugs was introduced to accompany the new legislation (Houborg 2008; Jepsen 2008). This policy outlined that the attorney general would issue a circular (no. I44 of I5/7 I969) that instructed the police and prosecution, as a main rule, not to initiate criminal proceedings that involved possession of illicit drugs for personal use. Were such proceedings initiated the main rule should be to limit the sanction to a caution and confiscation of the drug. The idea that drug use was socially determined played an important role in the development of this policy, along with reference to the legislative process when the Law on euphoriant substances was enacted where criminalization of drug users was defined not as an end in itself, but as a means to stop drug distribution.

The day that the parliament passed the new drug legislation it also debated Danish drug policy in general. One of the issues raised in this debate was whether or not to legalize cannabis. A majority of the members of parliament did not outright dismiss the idea. Rather, it was decided that in two years' time, in I97I, parliament should revisit the issue when hopefully more knowledge was available (Storgaard 2000). In I97 I, when the issue was revisited, parliament decided to maintain the prohibition against 
cannabis. However, at the same time parliament confirmed the policy of depenalization of drug users.

The drug policy that was developed during the late I960s and early I970s can be said to be a 'dual track' drug policy (Hakkarainen, Tigerstedt, \& Tammi 2007), where the criminal justice system should reduce drug supply while the social welfare system, including the new drug treatment system, should reduce drug demand. This policy was based on the idea that drug use and drug problems were not something 'alien' to Danish society but were a 'normal social problem' (Grapendaal, Leuw, Nelen, \& Nelen I995; Houborg 2006; Leuw I99I), that is, something that had structural causes, particularly associated with social and cultural change and the social conditions of certain groups of children and young people in Denmark. For the majority of parliament, this came with concerns about the potential exclusionary and alienating consequences of a policy of criminalization in relation to the many 'normal' young people who experimented with drugs. The state therefore collectivized much of the responsibility for reducing drug demand and, rather than excluding drug users, the drug policy aimed to include drug users in society by addressing the social problems that caused drug use. It is, however, important to note that the policy aimed at use reduction, not harm reduction. This means that reducing the risks associated with active drug use was not included in the drug policy as public responsibility. Harm reduction did not become a part of Danish drug policy until the r980s.

\section{0s: Introducing Harm Reduction, 1990s: Increase in Drug Use}

The most significant development in Danish drug policy during the I980s was the introduction of the idea of harm reduction in I984 - although this concept was not used, 'graduated goals' treatment goals were used instead (Houborg 2006). During the I970s and early I980s a growing number of problematic drug users could not, or would not, make use of the social treatment institutions that had been developed during the I960s and I970s. These institutions conducted abstinence-oriented 
psycho-social treatment, but an increasing number of 'older' drug users found the treatment paternalistic or could not meet the requirements (abstinence) for receiving treatment. A consequence of this was an increasing number of older, untreated drug users, who instead became a growing part of the population of institutions for homeless people and other institutions for socially marginalized people.

Since the early I970s methadone had been a contested issue in Danish drug policy. Some drug users, their relatives, and some doctors argued that methadone maintenance treatment should become part of the drug treatment system. But the drug treatment system and drug experts, including the committee on youth-narcomania, rejected this as medicalization of a social problem (Houborg 2006, 20I3). As a consequence, a kind of dual treatment system developed: drug-free public treatment and medical private treatment provided by general practitioners. In 1984 the Alcohol and Narcotics Council (which has replaced the committee on youth-narcomania) issued the report 'At møde mennesket hvor det er ...' [To meet the person where they are at] (a quote from Kirkegaard) (Narkotikarådet I984) as a response to the growing number of untreated (older) drug users who were increasingly affected by severe medical, mental, and social problems. The report recommended that the treatment system should provide services for these drug users, even if they continued to use drugs. Rather than only aiming for abstinence, the treatment system should work with 'graduated goals', which meant that it should work towards improvements in all aspects of the clients' social, medical, and mental situation, or prevent these areas from worsening. The Council said:

Drug abusers who do not feel an immediate need to stop the [drug] abuse [misbruget] - or who are not capable of doing it at a particular moment of time - should not fall outside the help of the treatment system. The treatment options should therefore not only aim at 'curing' the [drug] abuse, but also provide rehabilitating measures while the [drug] abuse goes on.

(Narkotikarådet I984: I33)

One of the instruments for doing this could be methadone maintenance treatment. The policy change that the Alcohol and Narcotics 
Council proposed required that Danish drug policy, and hence the Danish state, would take responsibility for mitigating some of the risks and harms associated with the lifestyle of a marginalized active drug user. In effect, the policy would mean extending the meaning and content of social citizenship for this part of the population by giving them access to new and more societal resources.

The new policy was met with scepticism by the drug treatment system and may not have been implemented if the HIV and AIDS crisis a few years later had not changed the parameters for drug policy discourse in Denmark. With the advent of HIV/AIDS, drug use through injection was no longer mainly a risk for drug users but became a public health risk for the entire population. For this reason, the Alcohol and Narcotics Council increased its efforts to roll out methadone treatment in Denmark. This was done, partly, by issuing new methadone guidelines that were much less restrictive than the previous ones (Narkotikarådet I988). However, this being said, it is important to have in mind that the introduction of harm reduction thinking in Denmark did not originally rest on public health concerns about reducing the risks associated with HIV/AIDS, but on a broader social welfare goal of providing care for a marginalized part of the Danish population. With these changes to Danish drug policy the state took responsibility for reducing and ameliorating some, but not all, of the risks and harms associated with being an active drug user in Denmark. One of the conditions for receiving methadone maintenance treatment was, for example, that the client did not use illegal drugs. If the client used illegal drugs, he or she could be expelled from drug treatment.

With regard to the other policy elements, the basic configuration of Danish drug policy as a 'dual track' policy was maintained. In the $\mathrm{I} 980$ s no new initiatives were introduced in relation to 'minor' drug offences (possession with intent of distribution and possession for personal use under the law on euphoriant substances). In relation to drug trafficking, the I980s and I990s saw the implementation of a number of initiatives that would give the police access to various 'untraditional' investigative tools (wiretapping, use of agents). During the years before the I980s the number of less serious cases under the Law on euphoriant substances had been declining, while the number of more serious cases under the 
penal code had been increasing. However, from I980 the number of 'minor' cases started to increase, continuing to increase during most of the I980s and until the early I990s, when there was a decline. The reason for the increase during the I980s may have been that the police allocated more resources to drug law enforcement (Storgaard 2000; Jepsen 2008).

Drug law offenses are not registered by type of drug (Mounteney et al. 2016), but the composition of police seizures provide an indication. From 2000-2016, amphetamine seizures have amounted to around $\mathrm{I} 2 \%$ of seizures, cannabis resin (hash) about $60 \%$, cocaine around $12 \%$, and heroin around $5 \%$ (Moeller 2019).

The increase during the early I990s, and the decline that followed, may be attributed to targeted police efforts against drug scenes in Denmark, particularly at Vesterbro in Copenhagen. In 1990 the Copenhagen police department introduced a stress-strategy against the open drug scene at Vesterbro. However, in 1994 the Minister for Justice intervened and had the attorney general issue a statement that affirmed the depenalization policy from I969 (Storgaard 2000: I49). This led to a decline in the number of cases (see Figure I).

We thus see how the police challenged the dual track policy by increasing their activities against minor drug law violations, but also that this resulted in a political reaffirmation of the basic

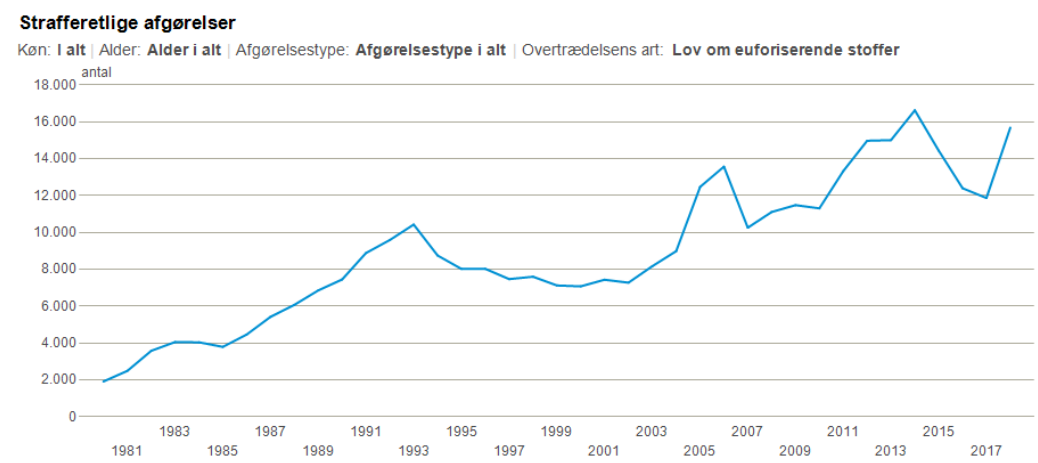

Figure 1. Criminal sanctions for violation of the Law on euphoriant substances I980-2017.

Source: Statistics Denmark, Statistikbanken Table: STRAF4O.

Note: It is not possible to separate cases involving possession and cases involving distribution under the Law on euphoriant substances. 
ideology of Danish drug policy as it had been established during the I960s and I970s.

During the I990s a number of legislative initiatives were implemented in relation to drug distribution, the most important of which was was the 'pusher act' (I996), which made it easier to sanction street dealers and expel foreign nationals for even minor drug law violations (Jepsen 2008).

Like all other western countries, Denmark saw an increase of drug consumption during the I990s, followed by a stabilization of the prevalence rates from 2000 to the 20 Ios (see Tables 5 and 6). Compared with European levels, Danes have a high lifetime prevalence ('ever'), but a past year prevalence close to the average European level (EMCDDA 20I7).

This increase was primarily for cannabis prevalence, but the introduction of a series of new amphetamine-like substances spurred further worry of a 'normalization' of illicit drug use and cultural accommodation (Parker et al. I999).

During the early I990s Denmark saw a sharp increase in the number of drug-related deaths (it has remained at this high level since then) (see Figure 2). From II 5 drug-related deaths in I990, the number rose to I 88 in I991, before rising even further during the following years to 268 in 1996 (Schmidt I997: I35).

Explanations that have been put forward for this include higher lethality among problematic drug users and purer and cheaper drugs (Schmidt I997). This situation led to discussions and increasing demands to introduce harm reduction measures, such as OST with heroin and drug consumption rooms. These discussions continued into the 2000 s.

\section{0s: Criminalization and Harm Reduction}

The 2000 s has seen a rather contradictory development of Danish drug policy. On the one hand, harm reduction policy was expanded with the introduction of maintenance treatment for heroin in 2008 and drug consumption rooms in 2012 . This was the continuation of a development that began in the I980s, with more and more risks associated with being an active drug user having been collectivized by offering public services. On the other hand, 


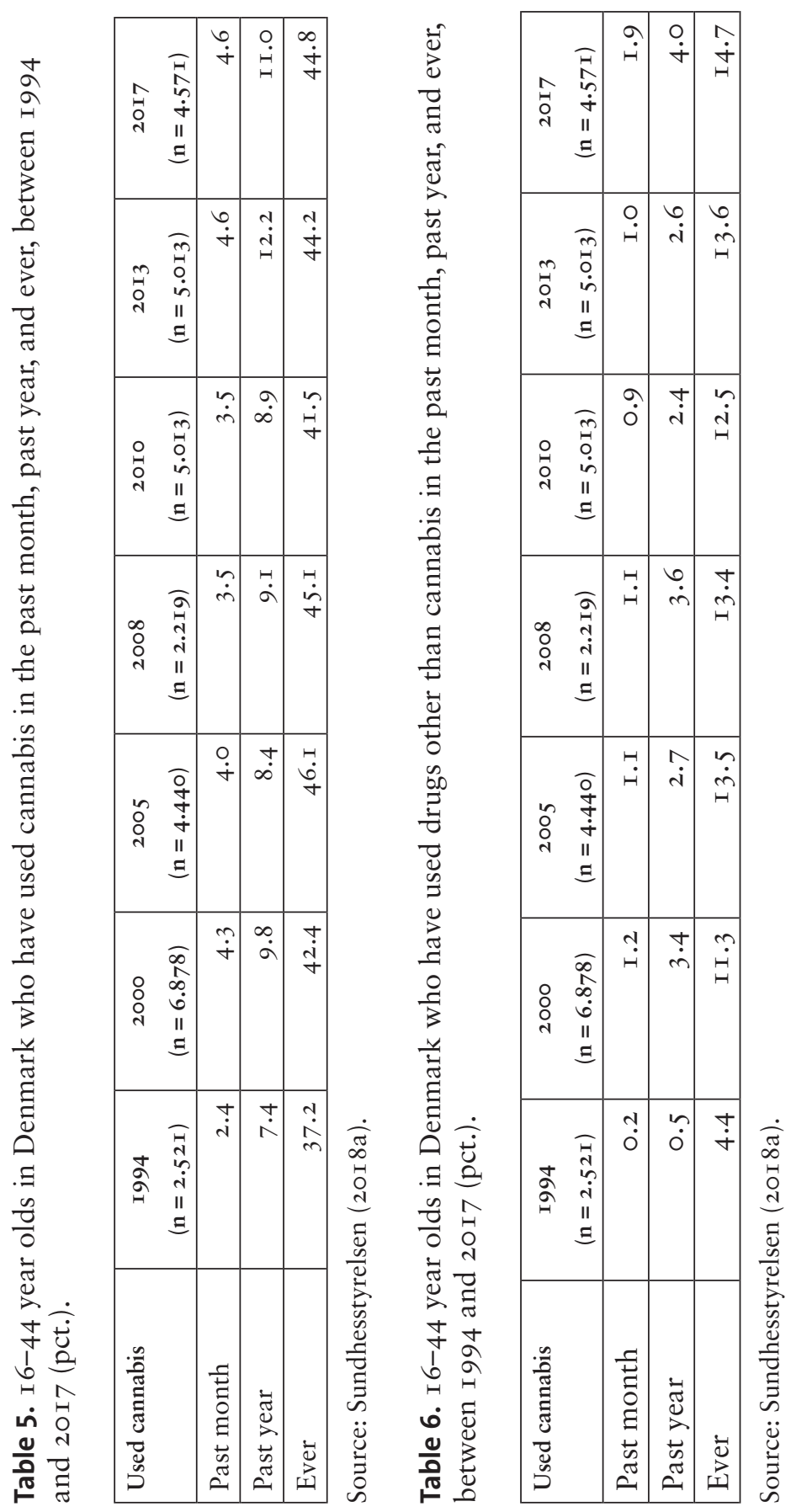




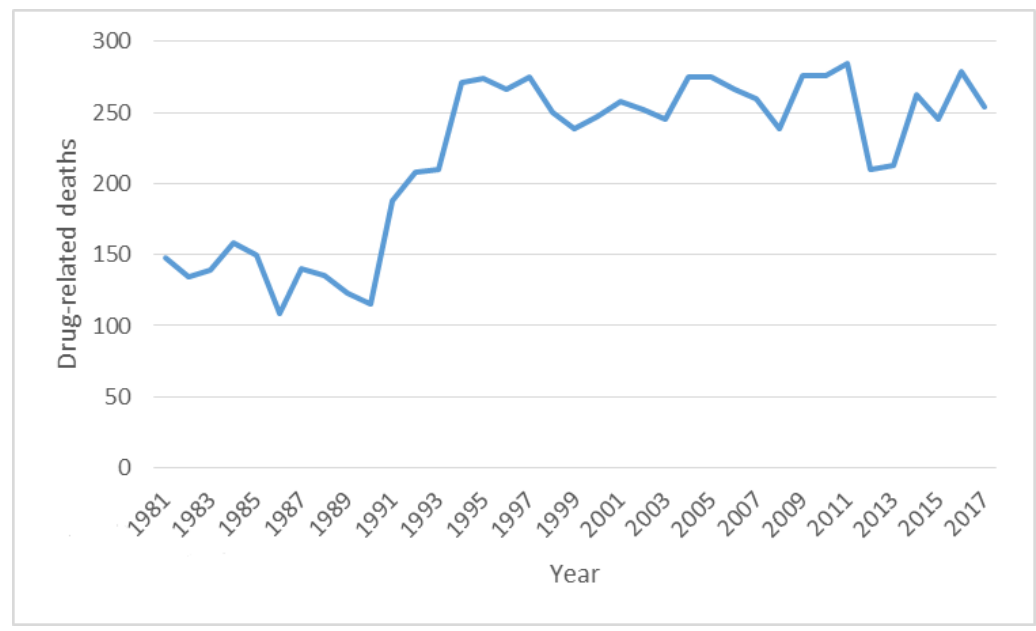

Figure 2. Drug-related deaths in Denmark, I98 I-20I7. Source: Sundhesstyrelsen (20I $8 \mathrm{~b}$ ).

Note: Based on the definition of a drug-related death from National Police: Any death where drugs were involved. This definition includes overdoses and other incidents, such as traffic accidents with fatal outcome, suicides, and homicides, where drugs were involved.

in 2004, an amendment of the Law on euphoriant substances repealed the policy of depenalization of drug users by making all possession of illegal drugs subject to punishment (except in special cases, which we return to). This meant that Danish drug policy, in part, turned away from the 'dual track' policy, whereby the social welfare system should reduce drug demand while the criminal justice system should reduce drug supply.

Various developments led to this policy change. The most important reason given was concern about a high level of consumption of both alcohol and illegal drugs among young people in Denmark compared with young people in other European countries. The policy change should, however, also be seen in the context of more general political strategy that aimed to 'responsibilize' the citizens and which included a stricter criminal justice policy. In the government whitepaper that accompanied the new policy it clearly expressed that the government wanted to send a signal that the use of illicit drugs was a criminal offence and that there were 'legal consequences' to violating the law (Houborg, Søgaard, \& Mogensen 2020). 
Through this policy, and the way it was ideologically framed, a new way of defining drug demand was articulated that differed from the definition that had been the basis for the dual track policy. Drug demand was now defined as partly a 'moral' problem and not, as it had previously been, as a 'social' problem. This meant that consumption of illicit drugs was now, to a larger extent, defined as a deliberate choice by the drug user and, to a lesser extent, seen as being structurally mediated, as it had been previously. Even if the policy change could be seen as an attempt to maintain a coherent drug policy in a situation with more drug users (Moeller 20I9), it should not be ignored that it was also an ideological change of how the relationship between drug users and the state was defined and how drug users were defined as citizens.

The introduction of zero tolerance has meant an increase of criminal sanctions for violating the Law on euphoriant substances (see Figure I). The decrease in 2007 is most likely caused by a large reform of the Danish Police that took place that year. After the introduction of zero tolerance, the proportion of cases that are settled with a caution has, as would be expected, decreased significantly, from $30 \%$ of the cases before 2004 to I-2\% after 2004 (see Tables 7 and 8) (Houborg \& Pedersen 20I3).

These figures show how Danish drug policy during the $2000 \mathrm{~s}$ has become significantly more punitive than it used to be, and suggest the end of a more 'purely' defined 'dual track' policy.

There is, however, one important exception from the punitive approach in the new policy. This involves people who are dependent on drugs and who, at the same time, have very few economic means (in effect, live on social assistance, early retirement pension, and the like). Such persons can still be let off with a caution. It is not completely clear from the law preparation work and the parliamentary debate why this exception was made. There were arguments that such drug users would not be able to pay fines and would then have to be imprisoned instead, at huge costs to Danish society. There were also arguments that their drug use was not (no longer) the result of a choice but was caused by their dependence, for which reason they should not be held legally accountable like non-dependent drug users.

In practice, the continued depenalization of 'poor and addicted' drug users has not been fully realized. Research conducted at the 
Table 7. Number of possession cases and how they have been settled, 2002-2008.

\begin{tabular}{|l|r|r|r|r|r|r|r|}
\hline Year & 2002 & 2003 & 2004 & 2005 & 2006 & 2007 & 2008 \\
\hline $\begin{array}{l}\text { Number } \\
\text { of cases }\end{array}$ & 6440 & 7263 & 8087 & I I,293 & I2,53I & 9342 & I0, I03 \\
\hline Sanction & $6 \mathrm{I} \%$ & $63 \%$ & $76 \%$ & $94 \%$ & $94 \%$ & $94 \%$ & $93 \%$ \\
\hline Caution & $30 \%$ & $30 \%$ & $\mathrm{I} 8 \%$ & $\mathrm{I} \%$ & $\mathrm{I} \%$ & $\mathrm{I} \%$ & $2 \%$ \\
\hline $\begin{array}{l}\text { Acquittal/ } \\
\text { charges } \\
\text { dropped }\end{array}$ & $9 \%$ & $7 \%$ & $6 \%$ & $5 \%$ & $4 \%$ & $5 \%$ & $5 \%$ \\
\hline
\end{tabular}

Source: Houborg \& Pedersen (2013).

Table 8. Number of possession cases and how they have been settled, 2009-20I3.

\begin{tabular}{|l|r|r|r|r|r|}
\hline & \multicolumn{1}{|c|}{2009} & \multicolumn{1}{c|}{$20 \mathrm{IO}$} & \multicolumn{1}{c|}{$20 \mathrm{II}$} & \multicolumn{1}{c|}{$20 \mathrm{I2}$} & \multicolumn{1}{c|}{$20 \mathrm{I3}$} \\
\hline Number of cases & I0,32I & 9889 & I 2,037 & I3,5I 5 & I3,447 \\
\hline Sanction & $93 \%$ & $92 \%$ & $93 \%$ & $94 \%$ & $95 \%$ \\
\hline Caution & $2 \%$ & $2 \%$ & $2 \%$ & $\mathrm{I} \%$ & $\mathrm{I} \%$ \\
\hline $\begin{array}{l}\text { Acquittal/ charges } \\
\text { dropped }\end{array}$ & $6 \%$ & $6 \%$ & $5 \%$ & $4 \%$ & $4 \%$ \\
\hline
\end{tabular}

Source: Houborg \& Pedersen (2013).

Centre for Alcohol and Drug Research has shown that this category of drug users is punished almost to the same extent as other drug users. The research compared convicted drug users who received social assistance or early retirement pension, and who were receiving, or had received, drug treatment, with other convicted drug users. ${ }^{\mathrm{I}}$

\footnotetext{
I This was how the target group for receiving cautions for 'social causes' was constructed in the research project, where drug treatment or drug treatment history was used as proxy for being drug dependent. But of course, it is not all drug users who are dependent on drugs - and who are 'poor' - who receive drug treatment. This means that the target group for cautions is larger than the one in the research project.
} 
Table 9. How cases involving persons receiving social assistance or early retirement benefit and who had been in drug treatment were settled, 2002-2008.

\begin{tabular}{|l|r|r|r|r|r|r|r|}
\hline Year & 2002 & 2003 & 2004 & 2005 & 2006 & 2007 & 2008 \\
\hline $\begin{array}{l}\text { Number of cases of } \\
\text { persons receiving } \\
\text { social assistance } \\
\text { or early retirement } \\
\text { benefit and who } \\
\text { had been in drug } \\
\text { treatment }\end{array}$ & 954 & 970 & II67 & I 538 & I6I7 & I057 & I295 \\
\hline Fine & $7 \mathrm{I} \%$ & $73 \%$ & $80 \%$ & $88 \%$ & $89 \%$ & $88 \%$ & $84 \%$ \\
\hline Suspended sentence & $3 \%$ & $2 \%$ & $2 \%$ & $2 \%$ & $2 \%$ & $3 \%$ & $2 \%$ \\
\hline $\begin{array}{l}\text { Caution } \\
\text { I9\% }\end{array}$ & $76 \%$ & I2\% & $3 \%$ & $4 \%$ & $4 \%$ & $9 \%$ \\
\hline $\begin{array}{l}\text { Acquittal/charges } \\
\text { dropped }\end{array}$ & $7 \%$ & $6 \%$ & $6 \%$ & $5 \%$ & $5 \%$ & $5 \%$ \\
\hline
\end{tabular}

Source: Houborg \& Pedersen (2013).

\section{Discussion and Conclusion}

Drug policy involves political priorities about the distribution of risks and costs associated with the presence of psychoactive substances in society. Closely related to this it also involves how drug users are defined as social citizens. Different drug policies involve different trade-offs with regards to risks, costs, and social membership. It is important for the development of drug policy that these political, and hence also ideological, dimensions of drug policy become explicit.

When looking at the development of Danish drug policy since the I960s, it becomes apparent how drug policy reflects historical changes of the political rationalities that have dominated welfare and penal policy.

When addressing the new drug problem of the I960s, the drug policy was dominated by a political rationality that also informed the development of the welfare state at the time. The drug problem was defined as a normal social problem that should be addressed like other social problems, through social welfare policy. It was 
an integrative drug policy that aimed to prevent young people becoming part of drug using subcultures and help individuals who had become part of such subcultures to leave them and become part of normal society. The policy explicitly rejected the criminalization of drug users because this was seen to work against the social integration of drug users in society.

The development of harm reduction as part of Danish drug policy during the I980 can be seen as an anticipation of a more general development in Danish social welfare policy that started during the late I980s. This development involved coming up with alternatives to the idea of social integration through normalization in the face of what came to be defined as 'social exclusion'. During the I980s, it had become apparent that not all citizens benefited from normalizing treatment and social rehabilitation, and would instead live socially marginalized lives excluded from the institutions that were meant to help them. From the late I980s, new methods and institutions were developed that aimed to provide differentiated services to socially excluded groups, with the aim of improving their everyday lives. The introduction of 'graduated goals' in Danish drug policy in I984 can be seen as part of this development. With it, new resources were allocated to the most marginalized drug users in Denmark, including access to methadone maintenance treatment, which previously had been very restricted because it was not seen to work towards social integration through normalization. With the graduated goals the Danish state took responsibility for addressing some of the risks and harms that were associated with being an active drug user in Denmark. From a drug policy point of view, it is significant that this introduction of harm reduction in Denmark was not mainly based on a public health ambition about reducing the spread of contagious diseases (HIV/AIDS), but on an ideology of care for a marginalized group in society.

The re-penalization of drug users in 2004 happened in a context where responsibilization of citizens was an important political goal and during a period where 'governing through crime' (Simon 2007) became an important governmental rationality. This meant that increasing emphasis was put on the moral habitus of citizens as autonomous and responsible individuals, and less on how 
social and structural conditions can influence how people act. During this period, criminal sanctions were increased. For example, parallel to the recriminalization of people who used illegal drugs, new sanctions were also introduced against violence near nightlife venues. The criminalization of drug users can be seen as the introduction of an exclusionary element in Danish drug policy that had previously been refrained from. The political rhetoric that accompanied the new legislation clearly signalled that punishment should delimit acceptable and non-acceptable behaviour in Danish society. In this way, the new policy introduced practices that did not include drug users, but rather excluded drug users as competent members of society.

This development can be seen as an articulation of a neo-liberal ideology (O’Malley I999). But what about the introduction of controversial harm reduction measures like OST for heroin and drug consumption rooms? The introduction of these measures did expand the drug-related risks that the state defined as a collective responsibility to handle. These measures, particularly drug consumption rooms, could be seen as measures that included the active drug user as an active drug user in society as a social citizen.

In this way, we see both excluding and including tendencies in Danish drug policy at the same time. This may, however, not be as contradictory as it seems because, as numerous researchers have shown, harm reduction can be seen as being informed by a neo-liberal ideology (Farrugia 20I4; Fraser \& Moore 2008; Moore 2004; Moore \& Fraser 2006). Harm reduction has been an important and empowering development for drug users. They are no longer defined as passive victims of drug-related harms and passive clients of expert interventions - they have become active, responsible, and autonomous agents in the management of risk. However, researchers have also pointed out that this empowerment can come with a price in two ways. First, particular normative assumptions about what constitutes good health and a responsible citizen in relation to health. Second, narrow definitions of the determinants of health, where focus is on the actions of the individual and the immediate environment of such actions, and not the more general social and structural conditions that affect the health and welfare of citizens. 
A distinction is sometimes made between harm reduction as a specific measure aimed at the reduction of particular harms, such as overdoses, HIV, Hepatitis, or other health harms, and harm reduction as a more general public health rationality that informs policy, for example, drug control policy. A number of countries have embedded public health into the foundation of their drug policies. This is not the case in Denmark. Successive governments have maintained the zero-tolerance drug control policy along with the harm reduction policy described. The history of Danish drug policy shows that public health is not the only path to drug policy reform. It is also possible, not as an alternative but as a supplement, to revisit the broader welfare policy ambitions that were used to inform drug policy in a much more prominent way than they do today.

\section{References}

Benoit, E. (2003). Not just a matter of criminal justice: States, institutions, and North American drug policy. Sociological Forum, I 8(2), 269-294.

Bruun, K., \& Rosenquist, P. (I980). Alcohol and drug control policies in the Nordic countries. Journal of Drug Issues, Io(4), $42 \mathrm{I}-432$.

EMCDDA (European Monitoring Center for Drugs and Drug Addiction) (20I7). European Drug Report 2017 - Trends and Developments. Lisbon: EMCDDA.

Esping-Andersen, G. (1990). The three worlds of welfare capitalism. Cambridge: Polity Press.

Farrugia, A. (20I4). Assembling the dominant accounts of youth drug use in Australian harm reduction drug education. International Journal of Drug Policy, 25(4), 663-672.

Fomiatti, R., Moore, D., \& Fraser, S. (2019). The improvable self: Enacting model citizenship and sociality in research on 'new recovery'. Addiction Research \& Theory, 27(6), 527-538.

Fraser, S., \& Moore, D. (2008). Dazzled by unity? Order and chaos in public discourse on illicit drug use. Social Science \& Medicine, 66(3), 740-752. 
Grapendaal, M., Leuw, E., Nelen, J. M., \& Nelen, H. (I995). A world of opportunities: Lifestyle and economic behavior of heroin addicts in Amsterdam. Albany: State University of New York Press.

Hakkarainen, P., Tigerstedt, C., \& Tammi, T. (2007). Dual-track drug policy: Normalization of the drug problem in Finland. Drugs: Education, Prevention and Policy, I4(6), 543-558.

Houborg, E. (2006). Stofmisbrug, metadon, subjektivering. Historiske og aktuelle fremstillinger af stofmisbrug. København: Sociologisk Institut.

Houborg, E. (2008). Youth, drugs and the welfare state. In V. Asmussen, B. Bagga, \& E. Houborg (Eds.), Drug policy: History, theory and consequences (I $8 \mathrm{I}-208$ ). Aarhus: Aarhus University Press.

Houborg, E. (2OI2). Kriminalisering af narkotika - den politiske og samfundsmæssige baggrund for kriminaliseringsprocesser i periode 1950-2004. In V. A. Frank \& H. Dahl (Eds.), Kriminalitet og illegale rusmidler (pp. I I9-I44). Aarhus: Aarhus Universitetsforlag.

Houborg, E. (20I3). Kampen om metadon i I970ernes Danmark. Bibliotek for Lager, 205, I.

Houborg, E., \& Bjerge, B. (20I I). Drug policy, control and welfare. Drugs: Education, Prevention and Policy, I8(I), I6-23.

Houborg, E., \& Pedersen, M. M. (2013). Håndhoevelse af narkotikalovgivningen vedr. besiddelse af illegale stoffer til eget forbrug efter 2004. København: Justitsministeriets forskningskontor.

Houborg, E., Søgaard, T. F., \& Mogensen, S. A. I. (2020). Making up a new drug user from depenalization to repenalisation of drug users in Denmark. International Journal of Drug Policy. Available online 2I January 2020.

Indenrigsministeriet (I953). Betænkning om misbrug af euforiserende stoffer. København: Indenrigsministeriet.

Jepsen, J. (I966). Marihuana i kriminologisk og juridisk belysning. In E. Thygesen (Ed.), Er marihuana skadelig? (pp. I69-248). København: Stig Vendelkærs Forlag.

Jepsen, J. (2008). Danish drug control policy I945-2007. In V. Asmussen, B. Bagga, \& E. Houborg (Eds.), Drug policy: History, 
theory and consequences (pp. I $5 \mathrm{I}-\mathrm{I} 80$ ). Aarhus: Aarhus University Press.

Kontaktudvalget (1969). Redegørelse for omfanget af en række akutte foranstaltninger mod ungdomsnarkomanien. København: Alkohol- og narkotikarådet.

Kontaktudvalget (I970). Redegørelse II om visse sider af stofmisbrugsproblemets udvikling og forslag til påtrængende foranstaltninger. København: Kontaktudvalget vdr ungdomsnarkomanien.

Leuw, E. (I99I). Drugs and drug policy in the Netherlands. Crime and Justice, I4, 229-276.

Manniche, E., Holstein, B. E., \& Boolsen, M. W. (I972a). Stofbrug blandt skoleungdom i Roskilde I972. København: Kontaktudvalget vedrørende ungdomsnarkomanien.

Manniche, E., Holstein, B. E., \& Boolsen, M. W. (I972b). En empirisk og teoretisk analyse af stofbrug blandt unge pa Bornholm I972. København: Kontaktudvalget vedrørende ungdomsnarkomanien.

Moeller, K. (2019). Sisters are never alike? Drug control intensity in the Nordic countries. International Journal of Drug Policy, 73 , I 4 I-I 45 .

Mounteney, J., Griffiths, P., Sedefov, R., Noor, A., Vicente, J., \& Simon, R. (20I6). The drug situation in Europe: an overview of data available on illicit drugs and new psychoactive substances from European monitoring in 2OI 5 . Addiction, I I I (I), 34-48.

Moore, D. (2004). Governing street-based injecting drug users: A critique of heroin overdose prevention in Australia. Social Science \& Medicine, 59(7), I 547-I 557.

Moore, D., \& Fraser, S. (2006). Putting at risk what we know: Reflecting on the drug-using subject in harm reduction and its political implications. Social Science and Medicine, 62, 3035-3047.

Mugford, S. (I99I). Towards a unified policy for legal and illegal drugs. In T. Camey, L. Drew, I. Mathews, S. Mugford, \& A. Wodak (Eds.), An unwinnable war against drugs: The politics of decriminalization (pp. 22-36). Leichardt, NSW: Pluto Press. 
Narkotikarådet (1984). At møde mennesket hvor det er. København: Alkohol- og narkotkarådet.

Narkotikarådet (1988). Metadonretningslinier. København: Alkohol- og Narkotikarådet.

O’Malley, P. (I999). Volatile and contradictory punishment. Theoretical Criminology, 3(2), I75-I96.

Parker, H., Aldridge, J., Measham, F., \& Haynes, P. (I 999). Illegal leisure: The normalisation of adolescent recreational drug use. Abingdon: Routledge.

Schmidt, D. (I 997). Narkotikasituationen i Danmark. In B. Olsson, P. Rosenquist, \& A. Stymne (Eds.), Narkotikasituationen $i$ Norden (pp. 39-68). Nordiska Nämnden för Alkohol- och Drogforskning: Helsingfors.

Simon, J. (2007). Governing through crime: How the war on crime transformed American democracy and created a culture of fear. Oxford: Oxford University Press.

Storgaard, L. L. (2000). Konstruktionen af dansk narkotikakontrolpolitik siden I965. København: Jurist- og økonomforlagets Forlag.

Sundhedsstyrelsen [National Board of Health] (2018a). Narkotikasituationen i Danmark. Delrapport I - Udbredelse af illegale stoffer i befolkningen og blandt de unge. Copenhagen: National Board of Health.

Sundhedsstyrelsen [National Board of Health] (20I8b).

Narkotikasituationen i Danmark. Delrapport 4 - Sundhedsrelaterede konsekvenser. Copenhagen: National Board of Health.

Tammi, T., \& Hurme, T. (2007). How the harm reduction movement contrasts itself against punitive prohibition. International Journal of Drug Policy, I 8(2), 84-87.

Turner, B. S. (I993). Contemporary problems in the theory of citizenship. In B. S. Turner (Ed.), Citizenship and Social Theory (pp. I-I 8). Sage Publishers: London.

Ulff-Møller, B. (I97I). Udbredelse af stofbrug blandt danske skoleelever. København: Kontaktudvalget vedrørende ungdomsnarkomanien. 
Ulff-Møller, B., \& Jørgensen, F. (I972). Spredning af stobrug blandt danske skoleelever fra I968 til I970. In J. Winsløw (Ed.), Ungdom og stofbrug (pp. 79-88). København: Jørgen Paludans Forlag.

Voss, T., \& Ziirsen, M. (I97I). Stofmisbrug - en samfundssygdom. København: Thanning \& Appels Forlag.

Winsløw, J., \& Holstein, B. E. (I972). Sociologi og stofbrug. In J. Winsløw (Ed.), Ungdom og stofbrug (pp. 9-35). København: Jørgen Paludans Forlag. 